Наприклад, на перших курсах студенти готують реферати, в яких розглядають цікаві особливості молекулярної біології на науковопопулярному рівні. Для прикладу. Як із неживих хімічних молекул водню, вуглецю, кисню та сірки складається злагоджена система в живому організмі? Як із одноклітинної заплідненої яйцеклітини (зиготи) формуються 220 різних типів клітин? Як працює ДНК, яка є сховищем спадкової інформації?

Таким чином, знайомлячи студентів і лікарів-інтернів із основами молекулярної біології на стику 3 класичною біологією, надіємося, що ці знання стануть фундаментальною основою для їх теоретичної підготовки, яка знадобиться подальшій практичній діяльності.

\title{
Література:
}

1. Бажора Ю. І., Чернецька О. В. Сучасні технології навчання. Одеський медичний журнал. 2010. № 4 (120). С. 33-37.

2. Бажора Ю. І. Фармакогенетика: досягнення та перспективи. 2003. $140 \mathrm{c}$.

3. Бажора Ю. І., Гончарук С. Ф. До проблеми інтеграції викладання медико-біологічних i клінічних дисциплін у медичних вишах. Ліки - людині. 2003. С. 401-403.

DOI https://doi.org/10.30525/978-9934-26-173-2-41

\section{ВИКОРИСТАННЯ МІЖДИСЦИПЛІНАРНОГО ПІДХОДУ У ПРОЦЕСІ ОБГРУНТУВАННЯ ЕКОНОМІЧНОЇ СКЛАДОВОЇ ПІДГОТОВКИ МАЙБУТНІХ ПЕДАГОГІВ ПРОФЕСІЙНОГО НАВЧАННЯ}

\author{
Ляшенко М. Ю. \\ кандидат педагогічних наук, дочент, \\ доцент кафедри теорії та методики професійної підготовки \\ Національний педагогічний університет імені М. П. Драгоманова \\ м. Київ, Україна
}

Щороку у закладах вищої освіти відбувається оновлення та удосконалення змістовного наповнення навчальних дисциплін як одного 3 важливих компонентів освітньої програми. Проте в останні роки спостерігається тенденція до зменшення економічної складової в навчальних планах педагогів професійного навчання. Актуальність 154 
даного питання полягає в обгрунтуванні не лише необхідності вивчення економічних дисциплін майбутніми фахівцями професійного навчання, а й використання при цьому міждисциплінарного підходу як можливість підвищення їх навчальної мотивації.

У дослідження науковців Ступницького О. І. та Приятельчук О. А. визначено, що міждисциплінарність припускає два загальноприйнятні підходи:

- перший обумовлює взаємозв'язок двох і більше дисциплін із суміжною термінологією, системою дослідження, об'єктами цих досліджень і т.д., причому ця сукупність допомагає досконало вивчити проблему дослідження, створює широке поле для наукових проектів. При цьому система знань для підготовки майбутніх фахівців здобуває сучасний вигляд і сприяє вирішенню наукових проблем;

- другий дозволяє розширити галузь знань, які не можуть повноцінно досліджуватися вже існуючими науковими дисциплінами, оскільки перебувають на межі їх перетину. Він сприяє поглибленню знань за умови, коли предмет дослідження занадто складний, а сформульована наукова проблема масштабна для однієї конкретної дисципліни [4, с. 137].

Підтримуємо науковця Олізько Ю., яка зазначає, що «міждисциплінарний підхід має значну кількість переваг серед яких: мотивація студентів до вивчення певної дисципліни, грунтовного осмислення та порівняння, застосування отриманих знань на практиці; можливість поновому представити вже відомий матеріал; розширення кругозору, підвищення самостійності та творчості студентів; інтеграція набутих знань, навичок та вмінь в одне ціле та сприйняття засвоєного протягом усього навчання матеріалу як нерозривної єдності; можливість реалізувати головні дидактичні принципи навчання» [2, с. 162].

Реалізація міждисциплінарного підходу при вивченні економічних дисциплін майбутніми педагогами професійного навчання буде можливою, якщо у навчальних планах буде поетапно реалізована економічна підготовка. Це є важливим питання, оскільки у 2019 році затверджено Стандарт вищої освіти зі спеціальності «015 Професійна освіта (за спеціалізаціями)», де визначено однією із загальних компетентностей майбутнього фахівця здатність виявляти ініціативу i підприємливість (К10) [3, с. 9].

Серед економічних дисциплін, які доцільно вводити в навчальні плани спеціальності «015 Професійна освіта (за спеціалізаціями)» ми виокремлюємо: 1 курс «Економічна теорія»; 2-3 курс «Економіка підприємства», «Організація виробництва»; 3-4 курс «Менеджмент», «Маркетинг». Розподіл дисциплін за семестрами повинен грунтуватися 
на принципах дидактики, серед яких виділяємо принцип систематичності і послідовності. Розкриття та обгрунтування студентам наявності міждисциплінарних зв'язків у процесі вивчення економічних дисциплін підвищує їх навчальну мотивацію, оскільки вони мають систематичне уявлення про здатність використовувати отримані теоретичні та практичні знання у своїй професійній діяльності.

3 допомогою міждисциплінарних зв'язків не тільки на якісно новому рівні вирішуються завдання навчання, розвитку і виховання студентів, а й закладається фундамент для комплексного бачення й оволодіння прийомами вирішення складних проблем реальної дійсності [1, с. 53].

Враховуючи вище сказане, нами пропонується введення в нормативну частину навчальних планів педагогів професійного навчання інтегративну дисципліну «Економіка та організація підприємницької діяльності», змістовне наповнення якої може забезпечити наступні програмні результати навчання відповідно до Стандарту вищої освіти зі спеціальності «015 Професійна освіта (за спеціалізаціями)»:

- ПР 07. Аналізувати та оцінювати ризики, проблеми у професійній діяльності й обирати ефективні шляхи їх вирішення.

- ПР 08. Самостійно планувати й організовувати власну професійну діяльність і діяльність здобувачів освіти і підлеглих.

- ПР 18. Розв'язувати типові спеціалізовані задачі, пов'язані 3 вибором матеріалів, виконанням необхідних розрахунків, конструюванням, проектуванням технічних об’єктів у предметній галузі (відповідно до спеціалізації).

- ПР 23. Розуміти соціально-економічні процеси, що відбуваються в Україні та світі, мати навички ефективного господарювання.

- ПР 24. Володіти основами управління персоналом і ресурсами, навичками планування, контролю, звітності на виробництвах, в установах, організаціях галузі/сфери [3, с. 10-11].

Теоретична та практичні знання отриманні 3 навчальної дисципліни «Економіка та організація підприємницької діяльності» можуть бути також використанні у процесі вивчення фахових дисциплін зі спеціальності: «015 Професійна освіта (готельно-ресторанна справа, туризм, харчові технології, документознавство)».

Водночас важливу роль у вставлені міждисциплінарних зв'язків відводимо викладачам. Тому що, як зазначають науковці Козлов В. В., Томашевська Т. В., Кузнєцов М. І., «ефективність міждисциплінарного навчання максимізується, коли професіонали 3 різних дисциплін працюють разом, щоб служити загальним цілям і допомагати студентам формувати зв'язки між різними дисциплінами або предметними сферами» [1, с. 54]. 
Отже, використання міждисциплінарного підходу дає можливість структурно виокремити лише ті економічні дисципліни, які є найбільш необхідними у підготовці майбутніх педагогів професійного навчання.

\section{Література:}

1. Козлов В. В., Томашевська Т. В., Кузнєцов М. І. Використання міждисциплінарних зв'язків при підготовці майбутніх фахівців зі статистики. Статистика Украӥни. 2018. № 1. С. 52-60.

2. Олізько Ю. Міждисциплінарний підхід як засіб реалізації основних дидактичних принципів навчання. Педагогічний дискурс. 2015. Вип. 18. С. 161-165.

3. Стандарт вищої освіти за спеціальністю «015 Професійна освіта (за спеціалізаціями)». Наказ МОН України № 1460 від 21.11.2019 р. URL : http://surl.li/awtgv

4. Ступницький О. І., Приятельчук О. А. Міждисциплінарний підхід до формування універсальних компетенцій у процесі вивчення дисциплін освітньої програми «міжнародний бізнес». Економіка та суспільство. 2021. № 25. URL : https://economyandsociety.in.ua/index.php/ journal/article/view/277 